\title{
Access to Justice: Recommended Reforms to the Ontario Justice System Using the Green Energy Act as an Example
}

\author{
Alan Whiteley' ${ }^{1}$ Anne Dumbrille ${ }^{1 *}$ John Hirsch ${ }^{1,2}$ \\ ${ }^{1}$ CCSAGE Naturally Green (County Coalition for Safe and Appropriate Green Energy), Picton, Canada \\ ${ }^{2}$ South Shore Joint Initiative, Picton, Canada \\ Email: *anne.dumbrille@gmail.com
}

How to cite this paper: Whiteley, A., Dumbrille, A., \& Hirsch, J. (2021). Access to Justice: Recommended Reforms to the Ontario Justice System Using the Green Energy Act as an Example. Open Journal of Social Sciences, 9, 1-19.

https://doi.org/10.4236/jss.2021.91001

Received: November 28, 2020

Accepted: January 8, 2021

Published: January 11, 2021

\section{Copyright $\odot 2021$ by author(s) and} Scientific Research Publishing Inc. This work is licensed under the Creative Commons Attribution International License (CC BY 4.0).

http://creativecommons.org/licenses/by/4.0/

(c) (i) Open Access

\begin{abstract}
Methods: A document was prepared and sent by a lawyer, Alan Whiteley, to Ontario government officials that identified the main concerns with the Green Energy Act and its impact on the rights of citizens. The Act had been introduced in 2009 in efforts to make Ontario a world leader in "green" energy production. With the passing of the Green Energy Act, a number of statutes were also amended in order to achieve this goal; they reduced impediments to the approval of industrial wind turbine projects. The letter in its entirety is included in this paper. Mr. Whiteley had been involved in a legal case initiated by a not-for-profit organization that argued that the regulatory changes impacted the rights of citizens. Documents such as those submitted through that court filings, such as Factums and Affidavits provided by Ontario residents, and other documents are referenced. Objectives: The goal of the letter was to affect modernization of the justice system to improve access to justice, citizen rights and animal protection. Results: The letter identified and described changes to Acts and policies, gave examples of impacts, and offered possible reform proposals that would allow citizens fair access to justice and protect their rights. These proposals were solutions through changes to the legal system. No reply to the letter was received from any of the government officials, increasing concern regarding the value of the voice of the public.
\end{abstract}

\section{Keywords}

Green Energy Act, Wind Turbines, Natural Justice, Access to Justice 


\section{Background}

In 2009, a former Premier of Ontario introduced new laws and modified many statutes in place in efforts to make Ontario a world leader in "green" energy production. The Green Energy and Green Economy Act (2009) was passed and statutes such as the Planning Act, the Municipal Act, the Endangered Species Act, and the Ontario Heritage Act were amended in order to achieve this with minimal interference to the approval and construction of wind turbine facilities from special interest groups such as the public or municipal governments $(\mathrm{CBC}$ News Report, 2009). The legislation and the implementation guidelines enabled these devices to be installed across rural Ontario in contravention of municipal bylaws, official plans and property assessment rights, and any local objections, as discussed in the letter below. Additional details and the resulting outcomes will be described in a subsequent paper.

Prior to the Green Energy Act being implemented, industrial sized wind turbine-related adverse health effects and effects on species at risk, including bats, eagles and other birds had been reported (Jeffery et al., 2014; Jones et al., 2009; Ontario Municipal Board Decision, 2007; Sprague et al., 2011; Standing Committee on General Government, 2009). After passing the Act, wind turbine projects were rapidly approved by the government across rural areas in the province: with the onset of operating wind turbines, residents living near the wind turbines submitted thousands of noise and health related Incident Reports/complaints to the Ministry of Environment (Krogh et al., 2019; Wind Concerns Ontario, 2020).

In the majority of areas in Ontario where approvals were given for these projects, people living near the proposed areas voiced concerns, particularly regarding their potential effects on human health, water quality, endangered species and their habitats. Many legal cases were filed (Wilson et al., 2020). The Act specified that the only legal recourse when objecting to an industrial wind turbine (IWT) project was to file an appeal to an Environmental Review Tribunal (ERT). The Act strictly limited what could be addressed: the appellant had to prove that engaging in the renewable energy project in accordance with the renewable energy approval will cause, 1) serious harm to human health; or 2) serious and irreversible harm to plant life, animal life or the natural environment (Green Energy and Green Economy Act, 2009).

By 2018, of the 80 applications by developers to obtain a project approval-an REA (Renewable Energy Approvals) to construct IWTs-only two were not approved, and two were revoked by ERTs (King et al., 2015; Kotsis, 2013; Rosengarten and Paulin, 2017; Province of Ontario Datasets; TBNewswatch 2015; complete list available on request).

When IWT projects were proposed in Prince Edward County, Ontario, a notfor profit group of concerned citizens-the County Coalition for Safe and Appropriate Green Energy (CCSAGE Naturally Green) approached lawyer Mr. Alan Whiteley. The Coalition was of the opinion that the approval process was biased 
and unfair to rural citizens. Mr. Whiteley agreed to represent it by filing a Judicial Review of the process by which a Renewable Energy Approval (REA) was issued in Prince Edward County.

It was considered by the lawyer that, although the goal of reducing greenhouse gas emissions of the Green Energy Act and related changes was noble, the changes in fact resulted in a reduction in access to justice and in citizen rights. In an effort to prevent future Acts and policy decisions from making similar mistakes, an analysis was made of the outcome of the changes, and sent to government officials with recommendations as to how they might be prevented in the future.

\section{Methods: Judicial Review-Records and Process}

In 2015, a Judicial Review was filed by CCSAGE Naturally Green by Mr. Whiteley as the legal representative (CCSAGE Naturally Green, Court File No. 15-2162). The Judicial Review requested that the Supreme Court of Ontario answer the following questions:

Is the REA that was issued to construct an industrial wind turbine project the result of institutional bias in the GEA and/or operational bias by the various Ministries?

Was the implementation of the GEA an infringement of natural justice and a denial of rights created under the Charter of Rights and Freedoms, in that residents of rural Ontario are discriminated against as turbines will never be located in urban communities?

The Judicial Review record included over 50 sworn affidavits prepared by individuals from across the province. Issues such as the GEA's removal of power from Municipalities and the lack of meaningful account of the impact on health, endangered species, and the local economy including tourism, property and business values were raised.

The Act to Terminate the White Pines Wind Project in Prince Edward County (Bill 2) was introduced after a change of government in 2018. Although this Act delivered a remedy being sought in the Judicial Review application (cancellation of the IWT project), the Charter challenge of the GEA was not addressed. In order to secure remedial action for owners of lands abutting operating wind turbines, an updated Application to the Ontario Superior Court was filed in 2019 to have the GEA declared discriminatory and thus unconstitutional (CCSAGE v. ONTARIO (AG)-Superior Court of Justice-Picton Court File CV-19-00000154-0000).

In December 2019, the Ontario Attorney General brought a motion to strike the court case on the following three grounds: 1) the applicant CCSAGE lacks standing to bring the application; 2) the application is moot, vexatious and an abuse of process; and 3) the application is devoid of merit. Alternatively, the office of the Attorney General asked to strike the paragraphs in the affidavits filed by the applicant that are irrelevant, legal argument, speculative and hearsay (Court File CV-19-00000154-0000, 2019). 
After four years, through both Liberal and Progressive Conservative governments, the non-profit organization withdrew the file due to an illness of Mr. Whiteley, and depletion of financial and other resources to conduct the case. See section "Acknowledgement".

During the four years of the court case, concerns regarding a lack of access to justice by citizens were identified by the representing lawyer, Mr. Alan Whiteley and others (Conroy, 2015a, 2015b; Goldstein, 2018; Krogh, 2011; McRobert, 2011; McRobert et al., 2016). Concerns ranged from issues such as: financial issues when the public takes the government and "deep-pocket" corporations to court; time constraints when the public has a mere two week window to hire lawyer(s) and collect adequate funding to file an appeal; the perceived bias of the GEA and its implementation to favour the wind turbine corporations over citizens; a lack of political influence of low-population rural areas where IWTs are located; and the limited jurisdiction of the Environmental Review Tribunal imposed by the GEA. These concerns identified weaknesses in the legal system that could generally affect the rights of citizens.

The Attorney General proposed to modernize the legal process, with a shift toward innovation and new technology (Ontario Newsroom, 2020). However, based on Mr. Whiteley's observations, the changes would have little or no impact on access to justice without fundamental changes to the substantive laws of Ontario. The idea of modernization of the legal process stimulated an analysis of the concerns resulting from legislation relating to the GEA that were identified during the preparation of the legal documents that supported the CCSAGE legal case. The main issues were identified, listed and described in a document. For each of these main concerns, possible changes to the legal process that could prevent or reduce the impact of those problems arising from new legislation were suggested. The goal was to affect changes to the legal process to prevent similar negative outcomes occurring with future legislative changes and to allow citizens fair access to justice. The document was offered to the government of Ontario within a letter.

\section{Requirement and Recommendations for Fundamental Changes to the Ontario Legal System: A Letter Prepared by Mr. Alan Whiteley}

The letter sent by Mr. Alan Whiteley, LLB (retired), to the Premier of Ontario, Attorney General of Ontario, Chief Justice of Ontario, Law Commission of Ontario, and others, on July 9, 2020 is included in its entirety, below.

\section{The letter reads:}

I am aware of circumstances that have brought the laws of Ontario into disrepute. The circumstances all relate to the Green Energy Act ("GEA") and its repeal, but they are indicative of a much larger problem, that of lack of access to justice. 
I take as my starting point the dictum of Justice Robert Jackson in American Communications Association v. Douds, 339 US 382, 442 [1950]

It is not the function of our Government to keep the citizen from falling into error; it is the function of the citizen to keep the Government from falling into error.

The circumstances I wish you to consider are instances in which the laws of Ontario prevented citizens from keeping the government from error. They are concrete examples of the problem identified by Justice Rosalie Abella of the Supreme Court of Canada in a recent lecture at Harvard Law School.

We can't talk seriously about access to justice without getting serious about how inaccessible the result, not the system, is for most people. Process is the map, lawyers are the drivers, law is the highway and justice is the destination. We're supposed to be experienced about the best, safest and fastest way to get there. If, much of the time, the public can't get there because the maps are too complicated, then, as Gertrude Stein said, "There's no there there." And if there's no "there there", what's the point of having a whole system to get to where almost no one can afford to go?

It was encouraging to learn that the Ministry of the Attorney General proposes to modernize the legal process, but the news release of May 2020 indicated that the main thrust of this modernization would consist of "shifting traditional investments toward innovation and new technology [which] will move more services online and position Ontario at the forefront of building the modern justice system of the future". While moving services online is long overdue, it will have little or no impact on access to justice without fundamental changes to the substantive laws of Ontario.

It is my hope that your consideration of the following circumstances will lead you to a clear realization of the fundamental changes required.

\section{PART ONE: LEGISLATIVE BIAS}

\section{Biased Policy}

The most charitable view of the GEA is that a former Liberal government thought that it would lead to lower electricity costs, lower carbon emissions and the creation of a manufacturing industry capable of exporting technology. The fact that the GEA led to increased electricity costs, increased carbon emissions and a reliance on foreign manufacturers and not only de-stabilized the province's electrical grid but drove industry out of the province indicates that the policy was bad policy.

But the GEA was also biased policy. In order to spread renewable energy plants across rural Ontario it was necessary for the government to suppress the rights of those who might object. In 2009 the Premier of Ontario stated that the purpose of the proposed GEA was to stop special interest groups or municipal governments from trying to block green energy projects for anything other than 
safety or environmental concerns. That was biased policy, and resulted in The Planning Act, the Municipal Act, the Endangered Species Act, the Ontario Heritage Act and other statutes of general application being amended or interpreted to remove any impediment to the approval and construction of IWTs, which were erected in contravention of municipal bylaws, official plans and assessment rights against local objections and continue to damage communities' economies, human health, land values and environments across rural Ontario.

Reform Proposal: When formulating policy that will deliberately infringe on the existing rights of some or all of the population, at least consult with those to be affected; audi alteram partem.

\section{Biased Consultation}

The GEA and its ancillary enactments and regulations were captured from the beginning by the wind power industry. Whether or not the wind power industry actually wrote the GEA legislation and regulations, as enacted they closely follow the proposal made by the Green Energy Act Alliance, a coalition of wind power interests.

When determining mandatory setbacks for Industrial Wind Turbines ("IWTs") the government held a Technical Workshop on Wind Turbine Noise to which it invited representatives of the IWT industry, all of whom submitted that the proposed requirement for infrasound or low frequency noise monitoring as a condition of the REA be removed. Despite evidence that IWTs generate a broad spectrum of emissions including low frequency noise and infrasound that may be inaudible ("LFN"), the government at the instance of the wind power industry removed from the GEA any requirement to monitor and address LFN.

Reform Proposal: When formulating policy, treat the regulated parties as counter-parties, not as clients.

3. Ignoring Binding Principles

Had the government consulted more widely, it would have discovered that the National Aeronautical and Space Administration ("NASA") reported in 1985 that the dynamic (acoustical) pressure field within a residential room is influenced by changes in the shape of the room caused by a diaphragm action from external pressure changes and that sub-audible acoustic energy can cause annoyance in homes when no perceptible sounds could be detected outdoors. IWTs emit sound pressure pulsations at infrasonic rates synchronized to the IWT hub rotation speed. Such emissions disrupt the normal functioning of the middle and inner ear, as well as that of other sensory organs, leading to nausea, impaired equilibrium, disorientation and elevated blood pressure. The low frequencies are easily transmitted into buildings, causing psycho-acoustical annoyance and sleep disturbance for residents.

Ontario's Statement of Environmental Values ("SEV") is stated to be a means for designated government ministries to be accountable for ensuring considera- 
tion of the environment in their decisions. The SEV mandates that Ministry of the Environment use a precautionary, science-based approach to protect human health and the environment. The GEA overrides many important protections in the SEV, including:

1) eliminates consideration of social and economic impacts to a community;

2) does not allow consideration of cumulative effects of multiple IWTs;

3) abandons the precautionary principle and shifts the onus to appellants;

4) bases REA decisions on incomplete, erroneous and unscientific reports.

Reform Proposal: When formulating policy that affects the environment, do not deliberately exclude the precautionary principle that is otherwise mandatory; and consider all factors.

4. Avoiding Environmental Impact Assessment.

Section 47.3(2) of the Environmental Protection Act ("EPA") states that s.9(1) of the EPA, which makes environmental compliance approval mandatory for all undertakings, does not apply to an IWT proponent who obtains a renewable energy approval ("REA") under EPA s. 47.5(1)(a). As a result, by stipulating only mandatory levels for emissions such as audible noise, the emission of other contaminants produced by IWT plants, such as $\mathrm{CO}_{2}$ from manufacture of cement, pollution of water by hydrocarbons or fracked sediment, or emissions of ILFN are not regulated or even considered.

Ontario used section 47.3(2) of the EPA to drive a coach and horses through environmental impact requirements,

Ontario issued an REA to Windlectric Inc authorizing the construction and operation on Amherst Island of 26 IWTs $156 \mathrm{~m}$ high with blades $55 \mathrm{~m}$ long. The REA authorized construction of a cement plant adjacent to the island's only school without any impact study. Initially Ontario held that the cement plant was not part of the REA and would require environmental compliance approval. The residents intended to challenge the application for the cement plant on the grounds that it did not comply with the Statement of Environmental Values, especially given the proximity to the local school. However, Ontario then amended the REA to add the cement plant as part of the "renewable energy project" thereby allowing construction and operation of a cement plant without any environmental assessment, without any input from the public and without any opportunity to appeal. Construction of a dock and underwater cable were dealt with in the same way.

Picton Terminals quarried aggregate at its site on Picton Bay and shipped it by barge to be used in the construction of wind turbine installations on Amherst Island. This was authorized by Ontario without any public review process by issuing an exemption on the grounds that Picton Terminal's primary objective was to improve access to the port and not aggregate creation. Thus Picton terminals was authorized to deliver up to $400,000 \mathrm{~m}^{3}$ (200,000 metric tonnes) of aggregate without any recourse to the Aggregates Resources Act or any other environmental assessment. The barge sank, polluting Picton Bay and incapacitating the municipal water system. 
Reform Proposal: When developing policy, don't deprive communities of legislation that protects their environment.

Ontario's erstwhile Environmental Commissioner deplored the attempt by the government to avoid public consultation on major environmental legislation by attempting to include it in a budget bill, stating that the government's "repeated decisions not to consult the public, fully or at all, deprive Ontarians of the opportunity to participate in the wholesale reconstruction of the way in which natural resources are to be managed in Ontario in the future".

Reform Proposal: Legislation that cannot withstand the light of public scrutiny is bad legislation.

Annually from 2010 to 2017 the Auditors-General of Ontario have issued reports highly critical of the GEA and the FIT policy of subsidizing proponents of IWT projects. Among the findings in those reports are the following:

1) billions of dollars were committed to renewable energy without full evaluation of the impact or any comprehensive business-case analysis;

2) generation capacity in Ontario had been much larger than required, demand was expected to remain flat, while supply was increasing;

3) between 2009 and 2014 electrical power excess to requirements was exported by Ontario at prices $\$ 3.1$ billion dollars less than the cost of production and Ontario paid an additional $\$ 339$ million to reduce production of surplus electricity;

4) the Respondent had entered into a major agreement with a Korean consortium for expansion of the IWT industry in Ontario with no economic analysis or business case;

5) consumers pay twice for intermittent renewable energy, once for the cost of constructing IWTs and again for the cost of constructing gas-fired generators needed only for the purpose of backing up IWTs.

The Ontario Society of Professional Engineers ("OSPE") has studied the efficacy of IWTs as a source of electricity in Ontario and as a method of reducing carbon emissions, and it has concluded that back-up generation is needed because of its low capacity and intermittence, so that adding IWTs to the grid will in fact double carbon emissions. They assert that it is mathematically impossible in Ontario to achieve low carbon emissions without nuclear generation.

Reform Proposal: When developing policy that will affect the entire economy of the province, consult experts, not the regulated industry.

\section{PART TWO: ADMINISTRATIVE BIAS}

...there may also exist a reasonable apprehension of bias on an institutional or structural level... if the system is structured in such a way as to create a reasonable apprehension of bias on an institutional level, the requirement of impartiality is not met.

Canadian Pacific Ltd. v. Matsqui Indian Band, [1995] 1 SCR 3 at Pp. 42-43

5. Biased Implementation

The GEA requires a minimum setback for each IWT of $550 \mathrm{~m}$ from the near- 
est "receptor" and $100 \mathrm{~m}$ setback from the nearest non-participating property line. The Government has never revealed on what basis the setbacks were established nor has it increased the setbacks to adjust for the increased size and capacity of newer IWTs.

Because of setbacks, noise levels, etc., IWTs could only be erected in rural areas. The GEA imposed industrialization across rural Ontario and deprived residents of the benefit of sound land use planning principles.

Reform Proposal: When Ontario imposes safety levels, it must have the burden of proving their efficacy.

\subsection{Setback Ignored}

Ontario granted an REA for the HAF Wind project on 20 June 2013. The project as constructed was non-compliant with 4 of its 5 IWTs at less than the prescribed setback, in breach of the REA conditions. The Environmental Review Tribunal refused to enforce the statutory minimum setback. The Ontario Ombudsman investigated this situation and confirmed that the developer had represented that its 5 IWTs would meet the statutory setback, that members of the public had identified the noncompliance during the comment period, that Ontario had taken no steps to resolve the non-compliance during the comment period. Ontario amended the REA after the fact to reduce the set-back below the regulatory minimum to the set-backs as built, depriving abutting owners of whatever benefit the mandatory setback provides.

\subsection{Nearby Receptor Ignored}

IWTs and a Transfer Station forming part of the Niagara Region Wind Farm surround an occupied home. The studies submitted by the developer and accepted by Ontario erroneously identified the home as a non-participating vacant property. Despite this egregious error, Ontario issued an REA authorizing the project, and immediately following commissioning of the project the home was exposed to vibrations and noise which have affected the occupant's health adversely. Despite numerous complaints, Ontario has failed to provide any resolution to issues including vibrations, interference with internet, stray voltage, shadow flicker or health impact.

Reform Proposal: No REA should deprive a resident of mandatory levels of environmental protection.

5.3. Well Water Polluted

A $4^{\text {th }}$ generation family farm in the Municipality of Chatham-Kent is located on the Kettle Point Black Shale Aquifer, from which it has drawn potable water for generations. As a result of the pile driving and construction of the 55 IWT facility called East St Clair and the adjacent 34 IWT facility known as North Kent 1, the waters of the aquifer are now contaminated with black shale particles known to carry heavy metals such as uranium, lead, mercury and arsenic. The water supply to the property and those of 17 neighbouring properties is no longer safe. The particles are smaller than one micron, such that they cannot be removed even by the finest filters and are easily absorbed through the skin. 
The water in a well in West Lincoln, adjacent to the Niagara Region Wind Farm, became contaminated with silt within months of the NRWF becoming operational. The sediment clogged filters and ruined a cold water tank, water softening unit, reverse osmosis system, hot water tank and rendered toilets inoperable.

Applying the precautionary principle under the Clean Water Act generally means that caution should be exercised in favour of groundwater or surface water protection, rather than waiting for irrefutable scientific proof that a particular land use activity or condition has adversely affected source water quality or quantity.

\subsection{Emissions Ignored}

In 2011 a person particularly susceptible to electrical sensitivities built a house specially designed to have low electromagnetic fields. He had to leave the house after the IWTs of the West Lincoln array began operation in proximity to his house. The IWTs release high frequency ground current and transient and harmonic signals making his house uninhabitable. The specific wave patterns of these emissions have been traced by experts to the types of inverter used in the West Lincoln IWTs.

The Enbridge Underwood 110 IWT project surrounds a century home. The owner has been unable to occupy her home since 2011. The noise from the Underwood project has rendered her home uninhabitable. She has filed over 440 noise complaints, without solution. Elevated levels of infrasound experienced at the S-residence match the signature of the Enbridge IWTs emitted by the Underwood project. Representatives of the Respondent have confirmed that such noise is "like a jet engine". Permission by the Respondent to emit noise in the audible spectrum is not permission to emit LFN or infrasound.

A retiree whose property abuts the NRWF sleeps in her unfinished basement in an attempt to alleviate the impact of infrasound on her body. She suffers from vertigo, tinnitus, delayed perception and depression. She is planning to move from her home because the environment is now toxic.

At

https://m.scirp.org/papers/101098?fbclid=IwAR3XcUKEebiBRsLAyIEbNpGHnP 3-EQU3 hwtOx4 ovfW6f-cI6JQj7Igfc is a study of the reasons why 67 families in Ontario have abandoned or contemplate abandoning their homes after wind turbines started up.

Fairness between the citizen and the state demands that the burden imposed be borne by the public generally and not by the plaintiff citizen alone.

Antrim Truck Centre Ltd. v. Ontario (Transportation) 2013 SCC 13 at paragraph 39

Reform Proposal: The burdens imposed on individuals by both regulated and unauthorized emissions authorized by state action must be remedied by the state.

5.5. Evidence Withheld

Ontario approved the Ostrander Point project on 20 December 2012; a citizen 
group appealed to the Environmental Review Tribunal ("ERT"), which revoked the permit on 3 July 2013 on the basis of findings that the project would cause irreversible harm to the Blanding's turtle. The proponent and Ontario appealed to the Superior Court and the citizen group further appealed to the Ontario Court of Appeal, which returned the matter to the ERT to determine whether the proponent could remedy the anticipated environmental harm.

At the remedy hearing before the ERT in August 2015 Ontario produced a surprise witness, Joe Crowley, who testified under oath that he was a herpetologist engaged by Ontario to review portions of the original habitat assessment by the proponent and to provide comments and recommendations prior to the approval of the Ostrander Point project. There had been no information about $\mathrm{Mr}$ Crowley or his review, comments or recommendations in the thousands of documents provided by the Respondent in response to a Request for Information made in October 2010, or at the original ERT hearing in 2013, or at the appeal hearing in the Superior Court, or in a subsequent Motion to Stay, or in the final appeal to the Court of Appeal. The ERT ordered Mr Crowley to produce all communications he had during the original assessment process for use at the remedy hearing. Mr Crowley finally produced a report entitled: Adult Blanding's Turtle Mortality and Population Decline, which concluded: "it is reasonable to conclude that road mortality at the site could result in the eventual loss of the population".

The people of Prince Edward County paid hundreds of thousands of dollars to protect Ostrander Point through 5 legal proceedings, all of which would have been unnecessary had the Respondent not withheld relevant evidence and breached its statutory duties in order to impose IWTs in an unsuitable location.

Reform Proposal: Apply proper discovery standards to administrative proceedings.

5.6. Evidence Ignored

A citizen group appealed to the Environmental Review Tribunal ("ERT") against the award of a Renewable Energy Approval ("REA") for the Snowy Ridge project. Their allegation was that the project would exceed permitted noise emissions and their evidence was that the project's Noise Assessment Report was seriously deficient in five major categories. The ERT struck the evidence of deficiencies on the basis that the ERT must assume that the regulatory limits would be met and could not consider evidence that the project would exceed those limits. Even where the manufacturer of turbines has specified higher noise levels for its products, the ERT has ignored that evidence and accepted the lower levels set out in the REA.

In issuing an REA, Ontario is required to act "in the public interest". The stated purpose of Part V.0.1 of the Environmental Protection Act, is to provide for the protection and conservation of the "environment", a term which includes 'the social, economic and cultural conditions that influence the life of humans or a community". Those conditions are the direct responsibility of the local mu- 
nicipality, but the municipality has no input and the EPA regulations require no investigation of such factors. The statutory appeal to the ERT prohibits these factors from any consideration by the tribunal. Consequently, the social, economic and cultural conditions in each

IWT project were completely ignored as was the impact of the REA and the IWTs on that community.

Reform Proposal: When providing a statutory appeal, apply ordinary standards of fairness and avoid bias.

\section{PART THREE: ACCESS TO EVIDENCE}

6. Those who have challenged the GEA and questioned the underlying policy have filed thousands of requests under the Freedom of Information and Protection of Privacy Act for particulars of proposed and operating IWT projects but have faced delays of years as the protection of privacy of proponents consistently impedes access to information for challengers. Those who suffer the environmental impact of IWTs have in turn filed thousands of Incident Reports about emissions by IWTs of pollutants both regulated and unregulated, but government has not acted and the few replies received have been evasive and non-responsive.

Reform Proposal: Implement complete transparency by legislating that no document submitted to influence government policy or decision shall be considered private.

On 20 September 2018 the Ontario government gave notice of the introduction of Bill 34 and stated the repeal of the GEA was necessary because it led to "the disastrous feed-in-tariff program and skyrocketing electricity rates... and took away powers from municipalities to stop expensive and unneeded energy projects in their communities". In the same notice the Respondent also admitted: "THE GREEN ENERGY ACT ALLOWED THE PREVIOUS GOVERNMENT TO TRAMPLE OVER THE RIGHTS OF FAMILIES, BUSINESSES AND MUNICIPALITIES ACROSS RURAL ONTARIO.”

After the repeal of the GEA, challengers believed that Government would be more forthcoming with the evidence in its possession. In Hansard and in press releases Ministers had repeatedly indicated that they opposed the GEA.

Minister of Energy Greg Rickford made the following statements: "The Green Energy Act represents the largest transfer of money from the poor and middle class to the rich in Ontario's history."

"The Green Energy Act forced wasteful projects on unwilling communities while driving up the costs of hydro bills for families and businesses across Ontario. These projects were forced on municipalities, with little to no consultation. When communities raised concerns, they were ignored, in fact trampled by Queen's Park."

Minister of Infrastructure Monte McNaughton made the following statements: "Well-connected energy insiders made fortunes putting up wind-farms and solar panels that gouge hydro consumers in order to generate electricity that Ontario 
doesn't need."

"The Green Energy Act allowed the previous government to trample over the rights of families, businesses and municipalities across rural Ontario."

"Wells that have produced clean, clear water for decades have begun producing dirty brown, unpotable water since construction of turbines for the North Kent I wind project began."

"I think this is just yet another example of the Liberal government showing disrespect to families in rural Ontario. If this happened in the GTA, they would shut these projects down immediately."

The foregoing statements and many others raised precisely the issues central to an Application made by CCSAGE, a not-for-profit corporation, for a declaration that the GEA violated s. 15 of the Charter of Rights, yet when CCSAGE sought to examine the Ministers to put their evidence before the court, the AttorneyGeneral asserted a privilege that allegedly exempts members of the legislature from giving any evidence in any proceeding while the legislature is sitting.

If there is such a privilege, it is of ancient origin at a time when members of the UK parliament had to travel between constituency and London by horse or coach. It was incorporated into Canadian law by the BNA but applied only to members of the federal parliament. Its extension to members of provincial legislatures has no basis in law, and in a day when examinations can be conducted easily and swiftly by internet, there is no practical reason to support such a privilege.

Reform Proposal: Make evidence known to members of the legislature available for consideration by the courts.

Instead of providing the evidence they have to support their statements, the Ministers identified above instructed the AG counsel to bring a motion to strike the constitutional challenge in its entirety. After four years of such resistance, through both Liberal and Progressive Conservative governments, CCSAGE's resources to conduct the case were depleted.

Reform Proposal: Avoid reverting to a "scorched earth" policy when responding to citizen challenges. A policy that cannot withstand scrutiny in court is not a fit policy for any government to pursue.

\section{PART FOUR: ACCESS TO COURT}

Citizens must have the right to challenge laws which they consider to be beyond the powers of the legislatures. If legislation excludes some people from receiving benefits and protection it confers on others in a way that contravenes the equality guarantees in the Charter, then the courts have no choice but to say so. To do less would be to undermine the Constitution and the rule of law.

Vriend v. Alberta [1998] 1 SCR 493 at p. $531 \& 532$

\subsection{Standing}

The traditional approach was to limit standing to persons whose private rights 
were at stake or who were specially affected by the issue. In public law cases, however, Canadian courts have relaxed these limitations on standing and have taken a flexible, discretionary approach to public interest standing, guided by the purposes which underlie the traditional limitations.

Canada (Attorney General) v. Downtown Eastside Sex Workers United Against Violence Society, [2012] 2 SCR 524, 2012 SCC 45 (CanLII) paragraph 1

A question of constitutionality should not be immunized from judicial review by denying standing to anyone to challenge the impugned statute. It would be strange and, indeed, alarming, if there was no way in which a question of alleged excess of legislative power, a matter traditionally within the scope of the judicial process, could be made the subject of adjudication.

\section{Thorson v. Attorney General of Canada, [1975] 1 SCR 138 at 145}

Unfortunately issues of standing are raised by respondents after applicants have incurred considerable time and expense in preparing a comprehensive record. Judges of the Superior Court automatically classify individuals directly affected by IWTs as ordinary litigants subject to the standard adverse costs award. This in itself creates litigation chill, as ordinary citizens are unwilling to risk their economic well-being in order to challenge government. The same judges classify applicants not directly affected by the challenged legislation as "officious inter-meddlers", ignoring Supreme Court of Canada decisions in Thorson and McNeil.

The real question is whether the applicant can show some substantial default or abuse, and not whether his personal rights or interests are affected.

Wade, Administrative Law, ( $7^{\text {th }}$ Edition) (1994) at p. 712, cited with approval in Corner

House Research v. Secretary of State for Trade \& Industry, [2004] EWHC 3011; [2005] 4 All E.R. 1 (C.A.) at paragraph 35

Proposed Reform: Establish a protocol similar to that for certification of class actions so that standing can be determined $a b$ initio.

\subsection{Adverse Costs}

Subject to the provisions of an Act or rules of court, the costs of and incidental to a proceeding or a step in a proceeding are in the discretion of the court, and the court may determine by whom and to what extent the costs shall be paid.

Courts of Justice Act, R.S.O. 1990, Chapter C.43, s.131. (1)

Like the traditional rules for standing, traditional cost rules tend to discourage rather than encourage litigation. Public interest litigants tend to be poorly funded. They are often dependent on the efforts of pro bono counsel and rarely have any prospect of a monetary award. If the lack of means to start the suit is not enough, the threat of an adverse costs award if the case fails can be a power- 
ful disincentive to launch the case in the first place.

Sharpe, Hon. Robert J., Access to Charter Justice, (2013), 63 S.C.L.R. (2d) at 6

A protective cost order can be justified where the respondent is a government, a public authority or a regulator as they are already within the public sector and can be expected to act for the public good.

Incredible Electronics v. Canada (Attorney General) (2006), 80 O.R. (3d)

723 at paragraph 106

From the perspective of a public interest litigant, not having to pay costs to the Attorney General but having to pay costs to the corporation profiting from the rights in question would be similar to avoiding a car only to be hit by a train.

Incredible Electronics v. Canada (Attorney General) (2006), 80 O.R. (3d)

723 at paragraph $108-109$

The English courts dealt with this problem in Corner House Research v. Secretary of State for Trade \& Industry, [2004] EWHC 3011; [2005] 4 All E.R. 1 (C.A.) at paragraph 28. Recognizing that access to justice is sometimes unjustly impeded if there is a slavish adherence to the normal private law regime, the court acknowledged that relaxing the traditional requirements of standing may be of little significance unless other procedural reforms are made. There is little point in opening doors if litigants cannot afford to come in.

Corner House established a procedure whereby public interest litigants could, when commencing a proceeding, seek a Protective Costs Order relieving them of any adverse cost award in the event that their challenge to legislation or administrative decision failed.

A protective costs order is appropriate in cases of general public importance where it is in the public interest for the courts to review the legality of novel acts by the executive in a context where it is unreasonable to expect that anyone would be willing to bear the financial risks inherent in a challenge.

Corner House Research v. Secretary of State for Trade \& Industry, [2004]

EWHC 3011; [2005] 4 All E.R. 1 (C.A.) at paragraph 52 and 74

Any Ontario court that has considered a protective costs order has done so only when the case has been concluded. This does nothing to relieve the litigation chill of the standard adverse costs award. But the Corner House doctrine provides for a much earlier determination, allowing unsuccessful applicants to withdraw well before incurring significant exposure to costs. The question of standing can be determined in a preliminary motion where the Applicant's interest in the substantive issues raised in the application is sufficiently clearly established by the allegations and contentions in the Notice of Application and the statutory provisions relied on without the need of evidence or full argument on the merits.

Finlayv. Canada (Min. of Finance), [1986] 2 S.C.R. 607 at 617 
Proposed Reform: Establish a protocol similar to that for certification of class actions so that entitlement to protective costs orders can be determined as a preliminary matter along with issues of standing.

\subsection{Party Costs}

Sophisticated and highly evolved rights and obligations are of little value if they cannot be asserted or enforced effectively and economically. Of what value is a right or obligation, or the judicial system itself, if its users must be told that the right is "too small" or "too complex" or "too risky" to justify its enforcement?

Report of the Attorney General's AdvisoryCommittee on Class Action Reform (1990) cited with approval in A.I.C. v Fischer [2013] 3 SCR 949 at paragraph 33

Even with a protective costs order, those who seek to challenge legislative or administrative bias face a huge disparity in resources in proceedings against government. A relevant feature in identifying a public interest litigant is that the litigant is either the "other", a marginalized, powerless or underprivileged member of society, or speaks for the disadvantaged in society. Such a litigant faces the powerful and experienced legal department of the Attorney General with few resources and pro bono representation, if available.

In such circumstances it is very easy for the responding AG to exhaust the limited resources of the applicant by means of interim proceedings well before the substance of the matter is heard.

Proposed Reform: Establish a government funded litigation group of qualified counsel to represent those who question government action.

\subsection{Representation}

A party to a proceeding that is a corporation shall be represented by a lawyer, except with leave of the court.

$$
\text { R.R.O. 1990, Reg. 194, r. } 15.01 \text { (2); O. Reg. 575/07, s. } 1 .
$$

Thus, an incorporated public interest litigant must either raise funds to retain counsel, seek pro bono counsel, or face the possibility that it may be denied access to justice if it cannot secure an order for self-representation. Superior Court judgements on when a corporation may be represented by an officer range from pro forma approval to denial after rigorous examination of corporate resources.

Modern corporation statutes provide that an entity incorporated under such act has the capacity and the rights, powers and privileges of a natural person.

The court would not question a self-represented individual about his or her decision to self-represent because that would be a denial of access to justice. There is no reason that the matter should be different with corporations.

Proposed Reform: Eliminate Rule 15 of the rules of civil procedure.

\section{Results and Conclusion}

The main areas included in the analysis of required changes to the legal system 
are:

1) Legislative bias in policy and consultation that reduced the ability of the public to object to the policy.

2) Administrative bias, where decisions are perceived to favour industry over a regulated industry over citizens.

3) Lack of timely access to evidence by the public.

4) Lack of access of the public to court due to financial and other concerns.

Recommended changes included, but are not limited to:

- having effective consultation with affected parties,

- consideration of regulated parties as counter-parties rather than clients or experts in the field,

- recognition of the value of previous legislation,

- proof by the government of the safety of defined required limits/levels, and that the safe levels are met by the regulated organizations or remediation given,

- having complete transparency by allowing public access to documents submitted to influence government policy or decision,

- reducing costs when the public question government action, by establishing a protocol similar to class actions to allow both an entitlement to protective costs and standing to be determined as a preliminary matter, by allowing a non-lawyer to represent a group whenever requested, and by establishing a government-funded litigation group to represent those who question such actions.

Such changes would allow those affected by legislative changes to have power to give considered input regarding the changes, and have access to justice if their concerns are not met.

No reply to the letter was received from any of the addressees. The lack of response to the letter adds concern regarding the described lack of access to consultation and justice in the province. It raises the following questions:

- Are letters from citizens received by senior officials?

- Are they read and seriously considered?

- Are senior officials discouraged from responding to letters on controversial topics?

- The Ministry of the Attorney General stated that there was a proposal to modernize the legal process. Is there a sincere intention to do so?

The Magna Carta stated: "to no one will we refuse or delay right or justice" (Magna Carta: Ch. 40). Yet, at present, Ontario's Acts have resulted in “justice delayed is justice denied", and in some cases, no justice at all. Justice is the right of all citizens. Can the Justice system be modernized to allow this right?

\section{Acknowledgements}

We acknowledge Alan Whiteley as the lawyer for CCSAGE, a not-for-profit organization based in Prince Edward County, with citizen members from across 
Ontario. He led the CCSAGE legal case against unsafe and inappropriate industrial wind turbines being imposed on unwilling rural municipalities because he believed the law to be wrong. He fought hard against an arbitrary policy that ignored the rights of citizens in the placement of turbines across the province. $\mathrm{He}$ argued for compensation for those suffering from living near them. He advised and managed the preparation of the more than 50 affidavits, and prepared the many related legal documents supporting the CCSAGE case, met with and advised those concerned and affected across the province, all on a pro bono basis. Prior to his death September 2020, he had concurred with the publication of his letter; his heir concurs with the final version submitted.

We also acknowledge the advice and input from Carmen Krogh in the preparation and submission of this manuscript.

\section{Conflicts of Interest}

The authors declare no conflicts of interest regarding the publication of this paper.

\section{References}

CBC News Report (2009). New Law Will Keep NIMBY-Ism from Stopping Green Projects: Ont. Premier. http://www.cbc.ca/m/touch/news/story/1.805978

Conroy, R. (2015a). Rule of Law. Wellington Times. Rule of Law. The Times (Wellingtontimes.ca).

Conroy, R. (2015b). Fixing a Bad Law. Wellington Times. Fixing a Bad Law. The Times (wellingtontimes.ca).

Court File No. CV-19-00000154-0000 (2019). Factum of the Attorney General of Ontario on Motion to Strike.

Goldstein, L. (2018). Why the Green Energy Act Had to Go: Good Riddance to Toxic Green Energy Act. Post Media. GOLDSTEIN: Good Riddance to Toxic Green Energy Act. Toronto Sun.

Green Energy and Green Economy Act (2009). S.O. 2009, Bill 105. Chapter 12, Ontario. An Act to Enact the Green Energy Act, 2009 and to Build a Green Economy, to Repeal the Energy Conservations Leadership Act, 2006 and the Energy Efficiency Act and to Amend Other Statutes. Assented in May 14, 2009.

Jeffery, R. D., Krogh, C. M. E., \& Horner, B. (2014). Review. Industrial Wind Turbines and Adverse Health Effects. Canadian Journal of Rural Medicine, 19, 21-26.

http://www.ncbi.nlm.nih.gov/pubmed/24398354

Jones, G., Bopper-Bohannon, R. I., Barlow, K., \& Parsons, K. (2009). Scoping and Method Development Report. Determining the Potential Ecological Impact of Wind Turbines on Bat Population in Britain. Phase 1 Report Final, Bristol: University of Bristol and Conservation Trust.

https://cdn.bats.org.uk/pdf/About\%20Bats/determining the impact of wind turbines on british bats final report 29.5.09 website.pdf? mtime $=20181105154128 \&$ focal $=$ none

King, R. J., Sadikman, J. A., Fairfax, J., Kirby, D., \& Coop, J. (2015). Ontario Court of Appeal Decides Ostrander Wind Farm Project and Sends Dispute Back to the ERT. Osler. Ontario Court of Appeal Decides Ostrander Wind Farm Project and Sends Dis- 
pute Back to the ERT (osler.com).

Kotsis, J. (2013). LaSalle Wind Turbine Project Rejected by Ministry. Windsor Star. LaSalle Wind Turbine Project Rejected by Ministry. Windsor Star.

Krogh, C. (2011). Industrial Wind Turbine Development and Loss of Social Justice? Bulletin of Science, Technology \& Society, 31, 321-333. https://doi.org/10.1177/0270467611412550

Krogh, C. M., Wilson, E. J., \& Harrington, M. E. (2019). Wind Turbine Incident/Complaint Reports in Ontario, Canada: A Review-Why Are They Important? Open Access Library Journal, 6, e5200.

McRobert, D. (2011). Intervenor Funding and Access to Environmental Justice: Time for the Ontario Political Parties to Revisit This Issue? David McRobert-Academia.edu.

McRobert, D., Tennent-Riddell, J., \& Walker, C. (2016). Ontario's Green Energy and Green Economy Act: Why a Well-Intentioned Law Is Mired in Controversy and Opposed by Rural Communities. (researchgate.net).

Ontario Municipal Board (2007). Decision/Order No: 1989. PL060986. Atcheson, J.P., Member. Testimony by d'Entremont, D., Brownell, R., Marshall, E., Connor, W. Issue Date July 16, 2007. PDF Copy Available on Request.

Ontario Newsroom (2020). Attorney General. Ontario Investing in Innovative Ways to Modernize the Justice System.

https://news.ontario.ca/en/statement/56891/ontario-investing-in-innovative-ways-tomodernize-the-justice-system

Province of Ontario. Renewable Energy Projects. Renewable Energy Projects-DatasetsOntario Data Catalogue; Renewable Energy Projects-Renewable Energy Projects. CSVOntario Data Catalogue (n.d.).

Rosengarten, J., \& Paulin, B. (2017). Canada: ERT Revokes Renewable Energy Due to Airport Impacts. Canadian Energy Perspectives. McCarthy Tétrault. ERT Revokes Renewable Energy Due to Airport Impacts. McCarthy Tétrault.

Sprague, T., Harrington, M. E., \& Krogh, C. M. E. (2011). Birds and Bird Habitat: What Are the Risks from Industrial Wind Turbine Exposure? Bulletin of Science, Technology \& Society, 31, 377-388. http://bst.sagepub.com/content/31/5/377 https://doi.org/10.1177/0270467611417844

Standing Committee on General Government (2009). Green Energy and Green Economy Act, 2009. Legislative Assembly of Ontario. Hansard. Ashbee B (pg G 516) and Ripley Group (pg G 547) April 15, 2009.

https://www.ola.org/en/legislative-business/committees/general-government/parliame nt-39/transcripts/committee-transcript-2009-apr-15

TBNewswatch. (2015). Province Officially Closes Big Thunder Wind Park File. https://www.tbnewswatch.com/

Wilson, J., Krogh, C., \& Peel, P. C. (2020). Déja vu and Wind Turbines: A Review of Lived Experiences after Appeals of Ontario Industrial-Scale Wind Power Facilities. Open Access Library Journal, 7, e6276. https://doi.org/10.4236/oalib.1106276

Wind Concerns Ontario: Response to Wind Turbine Noise Complaints (2020). Third Report 2017. (windconcernsontario.ca).

http://www.windconcernsontario.ca/wp-content/uploads/2020/02/Wind-Turbine-Nois e-Reports-to-MOECC-in-2017-FINAL-3.pdf 